\title{
J. S. Clarkson Letter on Civil Rights
}

\author{
Edited by Albert Fried
}

The letter edited in the following article may be found in the Gen. James B. Weaver Correspondence, Manuscript Division, Iowa State Department of History and Archives. It recently came to Mr. Fried's attention in the course of his research for a study of the Progressive Movement. $\mathrm{He}$ is completing his doctorate at Columbia University while an instructor in history at Brooklyn College.

The most serious erosion of Negro civil rights since Reconstruction occurred between 1890 and 1920. Jim Crow laws were passed in every community in the South. Negroes were disenfranchised en masse. Negro lynchings grew in numbers and in cruelty - and not alone in the South. Perhaps the blackest mark in Theodore Roosevelt's public career was his summary dismissal, November 5, 1906, of an entire battalion of Negro soldiers because they refused to identify the dozen or so among them who shot up the town of Brownsville, Texas. Six members of this unit wore the Congressional Medal of Honor. The "Brownsville episode" served to confirm a long evident fact-the Republican party, its rhetoric notwithstanding, had turned its back on the Negro. The status of the Negro reached its nadir when the Democratic administration of Woodrow Wilson officially instituted a policy of segregation in public office.

Many prominent Americans, of course, recoiled from this melancholy course of events. Arnong them was James S. Clarkson of Des Moines. He was one of the powers of the Republican party in Iowa in the years following the Civil War. Editor and associate publisher of the Des Moines Register between 1869 and 1891, Clarkson served as chairman of the Republican state central committee for many years, as delegate to every Republican national convention from 1876 through 1896, as an important member of the party's national committee from 1880 to 1896 , and as chairman of the Republican League from 1891 to 1893. Clarkson continually championed Negro rights, even to the detriment of his political career, resign- 
ing as postmaster of Des Moines in 1877 out of disagreement with President Hayes' policy of submitting to the South on Negro civil rights.

President Harrison appointed the Iowan first assistant postmaster general in 1889, one of Clarkson's tasks being to replace some 60,000 Democratic office holders. He paid special attention to the claims of southern Negroes for office, however distasteful it was to the sensibilities of southern Democrats. Senator Matt W. Ransom of North Carolina protested to him one day: "You can readily see how unpleasant it must be for the refined, cultured people of the South to take their letters from the hands of coarse negroes." Clarkson rejoined: "Does not a colored servant cook your meals, another wait on your table, another shave your face, and still another mix your toddy for you? You admit that. Well, then, I'm unable to see why it is that if as babes you can take your breakfast from black breasts, you can't also take your letters and newspapers from the hands of negro Postmasters. At the office in question, Senator, a colored man will be appointed before night." 1

This serves to introduce a remarkable letter written by Clarkson, January 16, 1907, while collector of customs at the Port of New York, setting forth his views on civil rights and social justice generally. It is a letter that speaks volumes, for it reveals his deepest values, his undiminished sympathy for a suffering race. It is all the more revealing since it was addressed to General James B. Weaver, the famous Iowa radical. Weaver had a long history of fighting for human rights, for the rights of labor, of farmers, of the middle class hurt by monopolies. He twice ran for the presidency as the candidate of third parties, the Greenback party in 1880 and the Populist party in 1892. On November 23, 1906 Weaver spoke at the dedication of the Iowa monument on the battlefield of Shiloh, where he himself had fought valorously. He took the opportunity in that speech to

1 This anecdote is given in Stanley P. Hirshson's excellent article, "James S. Clarkson and the Civil Service Reformers, 1889-1893," Iowa Journal of History, Vol. 57 (July, 1959), pp. 269-270. 
suggest a "solution" to the Negro problem, asserting that "America is not the negro's habitat. Let the whole negro race in this country," he said, "set their faces toward Africa and a black republic." Clarkson's letter answered Weaver in language that must have sounded familiar to the old radical's ears. In the passion of its righteousness it more than matches Weaver's own advocacy of civil rights in the past.

Except for minor deletions the letter is herewith printed in full.

January 16th, 1907

My dear General Weaver:

... Now as to your proposition,-naturally enough, in your letter you seem to know that I would not approve of it. You and I can differ as we have many times differed and remain in good nature. The only surprise I have over your Shiloh speech is that you made it. I would have staked a good deal on your having been, because of your nature and your fearlessness and your manly regard for other people's rights and the broad sweep of your humanity, a fearless advocate of the under dog. Your sympathies have always gone out to every man in trouble, and especially to the humble and the weak plunged into difficulty because of no fault of their own. You have, too, such a high sense of patriotism and love of country that I supposed you would put yourself in the colored man's place and therefore feel that a colored man born in America could have and would have the same love for this Republic that you and I have as white men and as natives. The negro did not come to this country voluntarily. He was brought here against his will, and, as time has proved, evidently against his interest. First he passed through two hundred years of servitude and cruelty and hardship, and, naturally, was much degraded by it and given no chance for development; but as a race and by his own blood, wherever it has demonstrated itself anywhere in the world, this race has been peculiarly home-loving, and indeed, has led the world in the folk songs of home and 
fireside and friends and the duty to be happy. It is a much more philosophical race than our race-yours and mine, - and it is a far happier race, even in its degradation, than our race is in this country in its superior position. So, when you say that these people, because they were born black, should have their troubles imposed upon them by the white man settled by sending them back to a black man's country, it is hard for me, believing in your generous heart, to believe that you are capable of such sentiment. Candidly and honestly, I see no more reason, no more right for a man to be deported from this country because he is black in skin than I do because he is a methodist in religion. In humanity or in the divinity of humanity or in human kindness a brother is not a sinner because he is weaker than we are; indeed, his very weakness appeals to the chivalry of strong men. This negro question, sometimes called a Southern question but in fact the great national question of our country and our century, is becoming to be appalling in its present state and still more so in its portent. . . . Every statesman who blinks the seriousness of this great fact and every political party which is dodging it is simply postponing a day of wrath, just as the generations before the war in our country postponed the day of evil, only to make it worse in the end. As you say so well in your speech, this is the second stage of this great question over the color of humanity,-a distinction which I do not recognize and which God himself, if he is the creator of us all, has not recognized. No Republic can base its suffrage on color, no Republic can base its suffrage on a basis of superior strength given to the strong as against the weak; no Republic could attempt such a basis and live; no Republic would be worthy to live on such a basis; no man of the highest type could find pride of citizenship in such a Republic. "Republic" would be a misnomer for such a country and such a people. I do not deny the great amount of ignorance in the colored race,-for which the white man, by his oppression, and not the colored man, 
however, is responsible. I am not of those who would willingly allow the negroes to vote who are ignorant and debased; neither am I among those who would allow white men who are ignorant and debased to vote. I believe in putting qualifications upon the suffrage, but in putting it upon all races alike; and if our boasted white race cannot stand this sort of competition with the black race we are not as superior a race as we claim to be.

The negro in the Southern States in the last forty years has demonstrated that he is a human being and evidently created by the same power by whom the white race was created. No race of any color-white or black or red-has ever made as much advancement in education, in the acquisition of property, in the desire to be good citizens and in proving it, as the blacks of the Southern States have in the last forty years. Today the negro in the South is not the lowest element by any means. There are more white men in the South who cannot read their ballots than there are black men. There is a far larger element of white people in the South who do not care for education and who refuse it, many times over, than there are black people. Put restrictions on the suffrage if you will, but not any such restrictions as the Southern States put in protecting white ignorance and in punishing both the intelligence and the ignorance of the blacks.

Again, your policy of deportation would be opposed by the South so strongly and so successfully that it could not be carried out without war, if the nation adopted it as a policy. Several attempts have been made to open the gates to the black people of the South, opening to them a country to which they could go to find peace and respectable life and a chance for growth, the same as our ancestors came to this country to find homes for themselves and all their descendants. Every time it has ever been tried, even when C. P. Huntington ${ }^{2}$ bought

2 Colis P. Huntington (1821-1900) rose from hardware merchant in Sacramento, California to builder of the Central Pacific and Southern Pacific railroads, along with Leland Stanford, Charles Crocker and Mark Hopkins. He was among the five richest men of the country. 
two million acres in Mexico and built three thousand cabins and sent his agents into the Southern states to get colonists, the South has always fought all such attempts almost to the point of war. Huntington's agents were driven out by mobs and barely escaped with their lives. The South is very perverse on this question; it will neither recognize the humanity and the rights of the negro at home nor allow him to go to any land where his rights can be recognized and would be. Our friend, Leigh Hunt, ${ }^{3}$ who bought five millions acres of land in the Soudan, running twelve hundred miles along the Nile, intending to open it up for the growing of cotton and tobacco and sugar and corn, saw in the Amercan negro the great cotton grower of the world, and he asked me to help him get bunches of hundreds from the cotton belts of the South to go as a colony and take up homes in the Soudan under him, much as the Mormons were taken to Salt Lake, with their fare paid to the destination, land sold to them on time and seed furnished and a cabin built, until they could repay it; when we came to take it up practically, we found it impossible with the present legislation and the present public opinion in the South, to carry out the plan. The South has hedged itself against such a thing by various kinds of legislation, the most serious of which is to charge $\$ 1,000$ for any agent in any county in which he tries to operate. The people of the different States and counties resist any such attempts and treat any agents going there for such purpose as if they were public enemies. The Southern people want the negro,--not as a human being, but as something below a human being who will give them both cheap and faithful work. To me, also, there is more involved than color in this question. If the negroes of the South, because they are poor and weak, can be degraded into a peonage which is worse than any state of

3 Leigh Hunt (1855-1933) became a businessman after serving as president of the state agricultural college of Iowa. He acquired mining and other properties throughout the world but chiefly in Asia. Clarkson refers to Hunt's plans for producing cotton in the Anglo-Egyptian Sudan. It turned out that Hunt succeeded without the use of American Negro labor. 
slavery ever was, then other elements of our population who are weak can be degraded, first into a peasantry and then into a peonage, and the always to be feared rule of money in our land will then be ushered in in the most serious possible way. Your plan to send the negroes away rather than to leave them to live in peonage is humane to that extent, but it could in nowise meet what the centuries are going to impose upon this nation as a problem,- the deepest of all problems which it has to meet,- the one which will require the wisest brains and the kindest hearts that any nation has ever had. The great victory of your life has been that you have won the confidence and the affection of millions of people by your championship of the rights of the weak and by your resistance of the encroachments of the strong and rich. You will allow an old friend and an old admirer, who you know speaks plainly only from conviction, to say that your speech at Shiloh is a solecism in your career. It is the first time so far as I know that you with your courage have ever surrendered to the demands of the strong against the weak, or the demands of people with money against people without money, or with the demands of a strong race against a weak race, but weak from no fault of its own. I have been studying this question by congenital instinct and momentum. The views that $I$ inherited from a race of Abolitionists were accentuated by seeing, when I was ten years old, a slave auction at Lexington, $\mathrm{Ky}$., in the Spring of 1852, when I went there from Brookville, Ind., with my father, who was called to Lexington by a letter from Henry Clay, who was then supposed to be on his death-bed. I spent two days seeing human beings sold and seeing them submitted to every sort of indignity which a human being of power could impose upon a human without power. I saw families sold apart, children sold out of their mother's arms, young women sold away from their parents for the uses of men alone, and women examined as horses are examined in horse marts, and every other sort of indignity put upon them,--and all done simply 
by the exercise of the right of power, which to me is not right at all. In Iowa my mother and I (who believed in a higher law) kept an underground station on Melrose Farm, in Grundy County, and I operated a section of the underground road from Melrose Farm to Hartford, Blackhawk County, 28 miles across the prairie; and about the proudest thing that I have in my life to remember is that in this way I helped four or five hundred human beings away from torture in a Republic to freedom in a Kingdom. I have always gloried in the courage of a negro who fought his way from slavery here to freedom in Canada, and when I was in Nova Scotia last Summer I had the pleasure of meeting the sons and daughters of some of the runaway slaves I helped by night across the prairies of Grundy County. I had a still greater pleasure in seeing them owning their own farms, respected by their neighbors, their children going to the schools the same as white children, and all of them happy in their homes in that little island,-which is almost an ideal Republic although it is under the shelter of a King. If the American negroes want to go to another country to find a better life and a fairer chance, Godspeed to them all,-and I wonder that a million or more of them do not go. Yet a race which has been suppressed for two hundred years hardly has the courage of initiation to venture out upon an unknown world as our forefathers did in coming here. But to say that we shall take the law of our nation, where the negro has always been tortured and misused, and strike him with it again, and strike him to go from the land of his nativity to God knows where, to a civilization which he would have to learn again and in which nine out of ten of them who should go would perish, is to suggest something which I do not believe you can defend or the American people ever allow to be tried. I try, and always have tried, to teach my children-born since the days of slavery and who are now unable to comprehend that the American Republic ever defended the ownership of human beings by other human be- 
ings,- that this Republic can never exist and be perpetuated in all its final glory of usefulness except by treating all people of all races alike and giving all people and all races an equally fair chance. You cannot do this by deporting from the country of the largest opportunity for freedom in the world, any race, white or black, without cruelty absolute and inevitable to any people so deported. At least such is the opinion of

Very truly yours, James S. Clarkson

Gen. J. B. Weaver

Colfax

Iowa

Clarkson's letter provokes a further observation. Civil service reformers reviled him-gibbeted might be a better word-for being a ruthless spoilsman who turned out thousands of able officeholders for the cardinal sin of being Democrats. In September, 1889, the Civil Service Record, a reform publication, told of one of Clarkson's appointees, an illiterate Negro postmaster of a village in North Carolina, who daily emptied the sack of mail in front of his office and had the residents pick it themselves. Clarkson, for his part, vigorously defended the spoils system. He held it to be eminently democratic, providing an opportunity for all men to hold office as a reward for service to their party. He admitted at the end of his career that he had been wrong in this, and that the reformers were right.

But in the light of this letter and the known facts of his career, Clarkson's duel with the civil service reformers compels us to ask what reform meant in the 1870's and 1880's. His opponents were far from being reformers on Negro rights and on the claims of the "weak against the strong" in our present day sense of the term. The reforming mugwumps or aristocrats wanted to purify politics. They would have deprived the politician of power by disenfranchising the lower classes, socially 
no less than politically. In other words, many politicians of the period, even corrupt politicians-and Clarkson was never accused of being corrupt-believed in democratic values which their mugwump critics rejected. And it is the ideals of the democratic politician, the ideals exemplified in Clarkson's magnificent letter, that have endured down to our time.

\section{M. \& M. R.R.-The Work Resumed}

The prospects for an early completion of the M. \& IM. Railroad to Brooklyn, in this county, are at present very flattering.-Work has been resumed on the road, and track-laying will be commenced in a few days. The stockholders of the road had a meeting at Davenport last week, and elected officers, who, it is understood, are in favor of pushing the road ahead to Brooklyn. A number of the stockholders came by special train to Marengo, the present terminus of the road, to view matters as they really stand. They found the road nearly all graded to Brooklyn, lying idle, and being sadly damaged by rains, \&c., and came to the wise conclusion that that portion of the road might as well be paying something as not, and consequently determined that the road should at least be completed to Brooklyn, and the cars run to that point. Our Brooklyn friends expect to hear the snorting of the "iron horse" in their suburbs in six or eight weeks. We trust they may not be disappointed.-Montezuma Republican. (Quoted in Davenport Daily Gazette, June 17, 1861). 
Copyright of Annals of Iowa is the property of State of Iowa, by \& through the State Historical Society of Iowa and its content may not be copied or emailed to multiple sites or posted to a listserv without the copyright holder's express written permission. However, users may print, download, or email articles for individual use. 